\title{
Effects of chitosan and whole raw soybeans on ruminal fermentation and bacterial populations, and milk fatty acid profile in dairy cows
}

\author{
F. Zanferari, ${ }^{*}$ T. H. A. Vendramini, ${ }^{*}$ M. F. Rentas, ${ }^{*}$ R. Gardinal, ${ }^{*}$ G. D. Calomeni, ${ }^{*}$ L. G. Mesquita, ${ }^{*}$ \\ C. S. Takiya, ${ }^{*} \dagger$ and F. P. Rennó* $\ddagger^{1}$ \\ *Department of Animal Nutrition and Production (VNP), University of Sao Paulo, Pirassununga, Brazil, 13635-900 \\ †Department of Animal Sciences and Industry, Kansas State University, Manhattan 66506 \\ łBursar 1-B of the National Council of Scientific and Technological Development-CNPq, Brasília, Brazil, 71605-001
}

\section{ABSTRACT}

The objective of this study was to evaluate whether providing chitosan (CHI) to cows fed diets supplemented with whole raw soybeans (WRS) would affect the nutrient intake and digestibility, ruminal fermentation and bacterial populations, microbial protein synthesis, $\mathrm{N}$ utilization, blood metabolites, and milk yield and composition of dairy cows. Twenty-four multiparous Holstein cows (141 $\pm 37.1 \mathrm{~d}$ in milk, $38.8 \pm 6.42 \mathrm{~kg} / \mathrm{d}$ of milk yield; mean \pm SD) were enrolled to a $4 \times 4$ Latin square design experiment with $23-d$ periods. Cows were blocked within Latin squares according to milk yield, days in milk, body weight, and rumen cannula $(\mathrm{n}=8)$. A $2 \times 2$ factorial treatment arrangement was randomly assigned to cows within blocks. Treatments were composed of diets with 2 inclusion rates of WRS (0 or $14 \%$ diet dry matter) and 2 doses of CHI (0 or $4 \mathrm{~g} / \mathrm{kg}$ of dry matter, Polymar Ciência e Nutrição, Fortaleza, Brazil). In general, CHI+WRS negatively affected nutrient intake and digestibility of cows, decreasing milk yield and solids production. The $\mathrm{CHI}$ increased ruminal $\mathrm{pH}$ and decreased acetate to propionate ratio, and WRS reduced $\mathrm{NH}_{3}-\mathrm{N}$ concentration and acetate to propionate in the rumen. The CHI reduced the relative bacterial population of Butyrivibrio group, whereas WRS decreased the relative bacterial population of Butyrivibrio group, and Fibrobacter succinogenes, and increased the relative bacterial population of Streptococcus bovis. No interaction effects between CHI and WRS were observed on ruminal fermentation and bacterial populations. The CHI+WRS decreased N intake, microbial N synthesis, and $\mathrm{N}$ secreted in milk of cows. The WRS increased $\mathrm{N}$ excreted in feces and consequently decreased the $\mathrm{N}$ excreted in urine. The CHI had no effects on blood metabolites, but WRS decreased blood concentrations of

Received March 1, 2018

Accepted June 5, 2018.

${ }^{1}$ Corresponding author: francisco.renno@usp.br glucose and increased blood cholesterol concentration. The CHI and WRS improved efficiency of milk yield of cows in terms of fat-corrected milk, energy-corrected milk, and net energy of lactation. The CHI increased milk concentration $[\mathrm{g} / 100 \mathrm{~g}$ of fatty acids (FA)] of 18:1 trans-11, 18:2 cis-9,cis-12, 18:3 cis-9,cis-12,cis-15, 18:1 cis-9,trans-11, total monounsaturated FA, and total polyunsaturated FA. The WRS increased total monounsaturated FA, polyunsaturated FA, and 18:0 to unsaturated FA ratio in milk of cows. Evidence indicates that supplementing diets with unsaturated fat sources along with CHI negatively affects nutrient intake and digestibility of cows, resulting in less milk production. Diet supplementation with CHI or WRS can improve feed efficiency and increases unsaturated FA concentration in milk of dairy cows.

Key words: chitin, fatty acid, oilseed, ruminal bacteria

\section{INTRODUCTION}

High-yielding dairy cows have relatively high energy requirement that often exceeds the nutrient intake capacity and consequently limits their milk production. In addition, the symbiotic relationship between ruminants and rumen microorganisms has energy and protein inefficiencies that results in methane eructation and excess of ammonia $\mathrm{N}$ production (Van Nevel and Demeyer, 1988). Microbial fermentation can be modulated to favor fermentation pathways that minimize losses either by promoting dietary changes (Beauchemin et al., 2008) or providing antimicrobials (Van Nevel and Demeyer, 1988). The use of ionophore antibiotics (e.g., monensin) in ruminant diets has shown to increase the rate of propionate production, decrease methane production, and reduce the ammonia accumulation in the rumen (reviewed by McGuffey et al., 2001). In addition, feeding ionophore antibiotics increased the total ruminating time during the day (Knowlton et al., 1996) and tended to decrease the meal interval time between meals in early lactating cows (Mullins et al., 2012). 
However, the ionophore utilization has been contested worldwide due to possible residues in animal products and the potential development of bacterial resistance, resulting in discontinued use in the European Union (European Commission, 2003). For these reasons, the search for alternative antimicrobials has attracted the attention of the scientific community.

Chitosan (CHI) is a biopolymer ( $N$-acetyl-D-glycosamide) derived from the deacetylation of chitin - the second most abundant polysaccharide in nature and the major component of exoskeleton from crustaceans and insects (Senel and McClure, 2004). Chitosan has demonstrated antimicrobial activity against several bacteria, fungi, and yeasts (Kong et al., 2010) and is considered generally recognized as safe by the US Food and Drug Administration since 2012 (GRN\#443; FDA, 2012). Chitosan interacts with the outer membrane proteins causing bacterial cell membrane disruption and cell death (Jeon et al., 2014). Although studies have evaluated CHI as an additive for silage preservation (Gandra et al., 2016a), or to prevent metritis (Daetz et al., 2016) and mastitis in dairy cattle (Lanctôt et al., 2017), few studies have evaluated the effects of CHI on ruminal fermentation in in vivo trials, especially with lactating cows (Paiva et al., 2016; Del Valle et al., 2017). Goiri et al. (2010a), Araújo et al. (2015), and Paiva et al. (2016) demonstrated the potential of $\mathrm{CHI}$ in decreasing the propionate to acetate ratio in ruminal fluid of sheep, beef steers, and lactating cows, respectively. Besides the effects on VFA production, evidence suggests that CHI decreases biohydrogenation in the rumen (Goiri et al., 2010b; Del Valle et al., 2017). Recently, Del Valle et al. (2017) reported that CHI improved the feed efficiency and increased milk UFA concentration of cows fed a soybean-oil-free diet. However, when CHI was provided in diets with soybean oil, these authors reported a negative associative effect on performance of cows. The reasons for the latter associative effect are not clear because no differences in nutrient intake and digestibility, and ruminal VFA concentration were detected between cows fed the diet with soybean oil and the diet with soybean oil along with CHI.

Lipid supplementation is a strategy to increase energy density of high-yielding cow diets, but depending on the form of diet supplementation (rumen-protected or not and unsaturation degree), it can decrease specific bacteria populations (particularly those belonging to the Butyrivibrio group) due to cytotoxic effects of UFA (Maia et al., 2007, 2010). Dietary fatty acid (FA) supplementation using whole oilseeds instead of ground oilseeds or vegetable oils has shown small negative effects on ruminal fermentation (Chilliard et al., 2009; Weld and Armentano, 2017). Whole raw soybeans (WRS) are considered a natural form of rumen-protected fat source that increases the abomasal flow of UFA (Barletta et al., 2016; Bettero et al., 2017). In addition, WRS have a lower price compared with their products (i.e., roasted soybeans) or other rumen-protected fat sources (i.e., calcium salts of FA).

We hypothesized that the negative interaction between CHI and UFA (soybean oil) supplementation on performance observed by Del Valle et al. (2017) would be eliminated by feeding CHI and WRS. We expected that CHI and WRS combination would improve ruminal fermentation, alter ruminal bacterial populations, and increase UFA concentration in milk of cows. The objective of this study was to evaluate the effects of CHI and WRS on nutrient intake and digestibility, ruminal fermentation and bacterial populations, microbial protein synthesis, $\mathrm{N}$ utilization, blood metabolites, and milk yield and composition of dairy cows.

\section{MATERIALS AND METHODS}

All procedures performed in the current study were approved (protocol no. 3059/2013) by the Ethics Committee in the Use of Animals from the School of Veterinary Medicine and Animal Sciences of University of São Paulo, São Paulo, Brazil.

\section{Animals, Experimental Design, and Diets}

Twenty-four multiparous Holstein cows $(141 \pm 37.1$ DIM, $38.8 \pm 6.42 \mathrm{~kg} / \mathrm{d}$ of milk yield, and $615 \pm 81.1$ $\mathrm{kg}$ of BW at the start of experiment), 8 of which were rumen cannulated, were enrolled in this study. Cows were housed in a barn containing individual pens (17.5 $\mathrm{m}^{2}$ of area) with concrete floor, bunks, sand beds, and free access to water. The experiment consisted of a 4 $\times 4$ Latin square design with 23 -d periods (last $8 \mathrm{~d}$ for sampling). Cows were blocked according to milk yield, DIM, BW, and rumen cannula. A $2 \times 2$ factorial treatment arrangement was randomly assigned to cows within blocks. Treatments were composed of diets with 2 inclusion rates of WRS ( 0 or $14 \%$ diet DM) and 2 doses of CHI (0 or $4 \mathrm{~g} / \mathrm{kg}$ of DM, Polymar Ciência e Nutrição, Fortaleza, Brazil). Chitosan dose was based on a previous study with beef cattle of our research group (Araújo et al., 2015) and further supported by an experiment with lactating cows (Mingoti et al., 2016). According to the manufacturer, CHI had an apparent density of $0.32 \mathrm{~g} / \mathrm{mL}, \mathrm{pH} 7.9$, viscosity of $50 \mathrm{cP}$ at $20^{\circ} \mathrm{C}$, and deacetylation degree of $86.3 \%$. Chitosan was hand mixed into the concentrate before the morning feed. Cows were fed TMR (Table 1) twice daily at 0800 
Table 1. Ingredient and chemical composition of experimental diets

\begin{tabular}{|c|c|c|}
\hline \multirow[b]{2}{*}{ Item } & \multicolumn{2}{|c|}{ Diet $^{1}$} \\
\hline & $\mathrm{CON}$ & WRS \\
\hline \multicolumn{3}{|l|}{ Ingredient, $\%$ of DM } \\
\hline Corn silage & 50.0 & 50.0 \\
\hline Ground corn & 29.2 & 23.9 \\
\hline Soybean meal & 18.0 & 9.50 \\
\hline Whole raw soybean & & 14.0 \\
\hline Urea & 0.44 & 0.22 \\
\hline Limestone & 0.15 & 0.15 \\
\hline Mineral and vitamin $\operatorname{mix}^{2}$ & 2.00 & 2.00 \\
\hline Salt & 0.20 & 0.20 \\
\hline \multicolumn{3}{|c|}{ Chemical, \% DM, otherwise stated } \\
\hline DM, $\%$ as fed & 58.5 & 58.7 \\
\hline $\mathrm{OM}$ & 93.3 & 93.5 \\
\hline $\mathrm{CP}$ & 17.3 & 17.4 \\
\hline Insoluble protein in NDF & 1.50 & 1.45 \\
\hline Ether extract & 2.44 & 4.76 \\
\hline NFC & 44.2 & 41.2 \\
\hline $\mathrm{NDF}$ & 30.7 & 30.8 \\
\hline $\mathrm{ADF}$ & 16.6 & 16.8 \\
\hline ADL & 2.68 & 2.70 \\
\hline Ash & 6.65 & 6.47 \\
\hline $\mathrm{NE}_{\mathrm{L}}, \mathrm{Mcal} / \mathrm{kg}$ of $\mathrm{DM}$ & 1.52 & 1.58 \\
\hline \multicolumn{3}{|l|}{ Fatty acids (FA), $\%$ of total FA } \\
\hline 14:0 & 0.40 & 0.39 \\
\hline 16:0 & 15.8 & 15.3 \\
\hline 18:0 & 3.14 & 3.22 \\
\hline cis-9 18:1 & 25.8 & 25.6 \\
\hline cis-9, cis-12 18:2 & 43.4 & 43.7 \\
\hline cis-9, cis-12, cis-15 18:3 & 4.22 & 4.71 \\
\hline$\Sigma$ MUFA & 26.1 & 25.9 \\
\hline$\Sigma$ PUFA & 47.7 & 48.5 \\
\hline SFA-to-UFA ratio & 0.28 & 0.28 \\
\hline
\end{tabular}

${ }^{1}$ Control (CON) and whole raw soybeans (WRS).

${ }^{2}$ Contained per kilogram of product: $100 \mathrm{~g}$ of Ca, $42 \mathrm{~g}$ of P, $18 \mathrm{~g}$ of S, $45 \mathrm{~g}$ of Mg, $20 \mathrm{~g}$ of K, $123 \mathrm{~g}$ of Na, $28 \mathrm{mg}$ of I, $500 \mathrm{~g}$ of Cu, $14 \mathrm{~g}$ of Co, $1,050 \mathrm{mg}$ of Fe, 1,400 mg of Mn, $18 \mathrm{mg}$ of Se, 2,800 mg of Zn, $420 \mathrm{mg}$ of F, $80 \mathrm{mg}$ of biotin, 200,000 IU of vitamin A, 40,000 IU of vitamin $\mathrm{D}_{3}$, and $1,200 \mathrm{IU}$ of vitamin $\mathrm{E}$.

and $1300 \mathrm{~h}$ in equal amounts, aiming refusals between 5 and $10 \%$ on an as-fed basis.

\section{Feed Chemical Analyses}

Feed ingredient and refusal samples were dried in a forced-air oven $\left(60^{\circ} \mathrm{C}\right.$ for $\left.72 \mathrm{~h}\right)$ and ground in a 1-mm-screen Wiley mill (Arthur H. Thomas Co., Philadelphia, PA). Ground samples were analyzed for DM (method 930.15), CP $(\mathrm{N} \times 6.25$, Dumas method 990.03), ether extract (EE, method 920.39), ADF and lignin (method 973.18), and ash (method 942.05) according to AOAC International (2000). Samples were analyzed for NDF content according to Mertens (2002), using thermostable $\alpha$-amylase with no sodium sulfite in the detergent. Insoluble $\mathrm{N}$ in NDF and insoluble $\mathrm{N}$ in ADF were analyzed according to Licitra et al. (1996). Organic matter was calculated subtracting ash content from DM. Nonfiber carbohydrate content was calculated as follows: $\mathrm{NFC}=100-(\mathrm{NDF} \%+\mathrm{CP} \%+$ $\mathrm{EE} \%+\operatorname{ash} \%)$. Total digestible nutrient and $\mathrm{NE}_{\mathrm{L}}$ were calculated according to NRC (2001).

For analyses of dietary FA profile, samples of ingredients were lyophilized and ground in a 1-mm-screen mill. Then, lipids were extracted according to Folch et al. (1957) and FAME formed according to Kramer et al. (1997). The FAME were quantified using a gas chromatograph (GC-2010, Shimadzu, Kyoto, Japan) equipped with flame ionization detector, automatic split injector (AOC-20i, Shimadzu), and capillary column of fused silica $(100 \mathrm{~m} \times 0.25 \mathrm{~mm}$ diameter) surrounded by $0.2 \mu \mathrm{m}$ of cyanopropyl polysiloxane pellicle (Rt-2560, Resetek, Bellefonte, PA). The temperature cycle in the gas chromatograph was programmed with the following steps: initial temperature of $70^{\circ} \mathrm{C}$ for $4 \mathrm{~min}$, an increase in temperature until it reached $175^{\circ} \mathrm{C}\left(13^{\circ} \mathrm{C} / \mathrm{min}\right)$ maintained for $27 \mathrm{~min}$, and a second increase in temperature until it reached $215^{\circ} \mathrm{C}\left(4^{\circ} \mathrm{C} / \mathrm{min}\right)$, which was maintained for $31 \mathrm{~min}$. Hydrogen was used as the carrier gas with a constant flow $(40 \mathrm{~cm} / \mathrm{s})$. The FAME were identified based on the retention time of FA standards [Supelco 37 Component FAME Mix, Bellefonte, PA; vaccenic acid, code V038-1G, Sigma-Aldrich, St. Louis, MO; trans-10, cis-12 CLA, code UC-61M, Nu-Chek Prep, Elysian, MN; and cis-9, trans-11 CLA, code. UC-60M, $\mathrm{Nu}-\mathrm{Chek}$ Prep]. Nonadecanoic acid was added as free FA to the samples to correct losses during the methylation process.

\section{Nutrient Intake and Total-Tract Apparent Digestibility}

Amounts of forage and concentrate provided, and refusals of each cow were weighed daily to calculate feed intake. Samples of diet ingredients and refusals were collected daily from d 16 to 23 of each period to form a composited sample per period per cow. Total-tract apparent digestibility of nutrients was determined after total feces collection from the 8 rumen-cannulated cows. Feces were collected from d 21 to 23 of each period from the pen floor, immediately after cows defecated, and were stored in plastic bags $(50 \mathrm{~L})$. During the total feces collection periods, the floor was constantly cleaned to avoid sand or feed particles in fecal samples. Total fecal output was weighed every $24 \mathrm{~h}$, and a representative sample ( $10 \%$ of total weight on a wet-basis) was frozen. Fecal samples were dried in a forced-air oven $\left(60^{\circ} \mathrm{C}\right.$ for $72 \mathrm{~h}$ ) and analyzed for DM, ash, CP, EE, and NDF, as described earlier. Fecal DM and nutrient excretion were estimated based on the chemical composition and fecal output from the $72 \mathrm{~h}$-collection period. Digestibility coefficients were calculated as $\{$ intake $(\mathrm{kg} / \mathrm{d})$ - fecal output $(\mathrm{kg} / \mathrm{d})] \div$ intake $(\mathrm{kg} / \mathrm{d})\} \times 100$. 


\section{Ruminal Fermentation and Bacterial Quantification}

Ruminal digesta samples ( $\sim 500 \mathrm{~g}$ from each site) were collected on d 19 of each experimental period from 5 different sites within the rumen (cranial sac - dorsal portion, cranial sac - ventral portion, ventral sac, dorsal sac, and ventral sac - caudal portion), pooled, and strained in 4 layers of cheese cloth to obtain ruminal fluid. Digesta samples were collected every $2 \mathrm{~h}$ relative to the morning feeding $(0800 \mathrm{~h}$ - time point 0$)$ until 12 $\mathrm{h}$ after. Ruminal fluid $\mathrm{pH}$ was measured immediately after the digesta collection (MB-10, Marte Científica, Santa Rita do Sapucaí, Brazil). Digesta was returned into the rumen after ruminal fluid was sampled. Fifty milliliters of ruminal fluid were centrifuged $(7,000 \times$ $g$ at $4^{\circ} \mathrm{C}$ for $15 \mathrm{~min}$ ), and $1.6 \mathrm{~mL}$ of supernatant was collected for VFA analysis. Another aliquot of the supernatant $(0.8 \mathrm{~mL})$ was collected and transferred to 2.0-mL centrifuge tubes containing $0.4 \mathrm{~mL}$ of sulfuric acid $\left(\mathrm{H}_{2} \mathrm{SO}_{4}, 0.5 M\right)$ for $\mathrm{NH}_{3}-\mathrm{N}$ analysis. The phenolhypochlorite colorimetric method was used to measure $\mathrm{NH}_{3}-\mathrm{N}$ concentration in samples (Broderick and Kang, 1980). Volatile fatty acid concentrations were measured using a gas chromatograph (GC-2104, Shimazdu) with splitless injector, capillary column at $145^{\circ} \mathrm{C}$ (Stabilwax, Restek), and double flame ionization detector at $250^{\circ} \mathrm{C}$, according to methods described by Erwin et al. (1961) and adapted by Getachew et al. (2005). Samples for VFA analysis were thawed at room temperature, centrifuged $\left(14,500 \times g\right.$ at $4^{\circ} \mathrm{C}$ for $\left.10 \mathrm{~min}\right)$, and $1 \mathrm{~mL}$ of supernatant transferred to chromatograph vials containing $0.1 \mathrm{~mL}$ of the internal standard (2-ethylbutyric acid $100 \mathrm{~m} M$, Chem Service, West Chester, PA). External standards were prepared (acetic acid, propionic acid, isobutyric acid, butyric acid, isovaleric acid, and valeric acid; Chem Service) to aid in the identification of peaks, and calculations of VFA concentration were performed by GCSolution software (Shimadzu).

On $\mathrm{d} 19$, the ruminal digesta collected $6 \mathrm{~h}$ after the morning feeding was also analyzed for bacterial quantification. Twenty-five grams from the solid portion and $25 \mathrm{~mL}$ from the liquid portion were processed according to Stevenson and Weimer (2007), then the bacterial pellet was resuspended in $700 \mu \mathrm{L}$ of buffering solution (Tris $100 \mathrm{~m} M, 10 \mathrm{~m} M$ EDTA, and $0.15 M \mathrm{NaCl}$; pH 8.0) and stored at $-80^{\circ} \mathrm{C}$ until DNA extraction. Two hundred microliters from the resuspended sample was used in the DNA extraction process using a commercial kit (Qiagen QlAamp DNA stool, Qiagen, Valencia, CA) according to the manufacturer's recommendations. An ethanol precipitation was performed as the last step of DNA extraction (Sambrook and Russell, 2001). Relative bacterial quantification was estimated by real-time PCR utilizing the ABI Prism 7500 detection system
(Applied Biosystems, Lennik, Belgium) and SYBR technology (Invitrogen, Carlsbad, CA) in 96-well microplates. Samples were analyzed in duplicate with a negative control for each bacterium assessed. Each well was filled with $10 \mu \mathrm{L}$ of $2 \times$ SYBR Green Master Mix (Life Technologies, Foster City, CA), $0.30 \mu M$ of primers for each bacterium specie, $6.6 \mu \mathrm{L}$ of nuclease-free water, and $1 \mu \mathrm{L}$ of extracted DNA, totaling a final volume of $20 \mu \mathrm{L}$ per well. Five bacterial taxa were quantified: Butyrivibrio group, Butyrivibrio proteoclasticus, Anaerovibrio lipolytica, Streptococcus bovis, and Fibrobacter succinogenes, whereas primers were selected based on GenBank (EU714406.1, AM039827.1, NR_114696.1, M58835.1, and EU606019.1, respectively). Forward (F) and reverse (R) sequences of bacterial primers were F: GYGAAGAAGTATTTCGGTAT and R: CCAACACCTAGTATTCATC for the Butyrivibrio group (Boeckaert et al., 2008; 418 bp); F: TCCGGTGGTATGAGATGGGC and R: GTCGCTGCATCAGAGTTTCCT for B. proteoclasticus (Paillard et al., 2007; 185 bp); F: TGGGTGTTAGAAATGGATTCTAGTG and R: GCACGTCATTCGGTATTAGCAT for A. lipolytica (Khafipour et al., 2009; 109 bp); F: TTCCTAGAGATAGGAAGTTTCTTCGG and R: ATGATGGCAACTAACAATAGGGGT for $S$. bovis; (Stevenson and Weimer, 2007; $127 \mathrm{bp}$ ); and F: GGTATGGGATGAGCTTGC and R: GCCTGCCCCTGAACTATC for F. succinogenes (Tajima et al., 2001; $445 \mathrm{pb}$ ). A general oligonucleotide (Eubacteria universal; F: GTGSTGCAYGGYTGTCGTCA and R: ACGTCRTCCMCACCTTCCTC; Maeda et al., 2003; 147 bp) was used to quantify total bacteria. Five bacterial targets were relative quantified to Eubacteria (16S ribosomal RNA gene). This universal primer was used for quantification of total bacteria for each ruminal sample individually, to standardize the amount of DNA added to the reactions. The standard curves were generated from a serial dilution $(\mathrm{n}=5 ; 100,60,30,15$, and $7.5 \%)$ from a pool of samples used in this study with the same DNA concentration. The quantitative PCR reactions of all bacteria were run in duplicate, and a negative control was included in each assay to assess the specificity of quantitative PCR reaction. No positive controls were designed. The PCR amplification protocol included an initial denaturation $\left(95^{\circ} \mathrm{C}\right.$ for $\left.10 \mathrm{~min}\right)$ followed by 44 cycles of heating $\left(95^{\circ} \mathrm{C}\right.$ for $\left.15 \mathrm{~s}\right)$ and cooling $\left(55^{\circ} \mathrm{C}\right.$ for $30 \mathrm{~s}$ ). A standard curve was designed for bacterial species and presented similar reaction efficiency of $E$. universal. The $\mathrm{Ct}$ method assumes that the efficiency of the PCR is close to 1 and the PCR efficiency of the target gene is similar to the internal control gene (Schmittgen and Livak, 2008). The relative quantification of bacteria was performed using the $2^{-\Delta \mathrm{Ct}}$ method (Livak and Schmittgen, 2001). 


\section{Microbial Protein Synthesis and N Utilization}

Microbial N synthesis $(\mathbf{m i c N})$ was estimated based on purine derivatives (PD) excretion through urine and milk as described by Chen and Gomes (1992). Total urine collection was performed during the last $3 \mathrm{~d}$ of each experimental period (Ahvenjärvi and Huhtanen, 2002; González-Ronquillo et al., 2003) from the 8 rumen cannulated cows concomitantly with total feces collection. Urine was collected via a Foley catheter inserted into the urinary bladder ( $12 \mathrm{~h}$ before collections) connected into a nontoxic polyvinyl chloride tube (1.2 $\mathrm{cm}$ diameter) plugged in a urine drainage bag (2L FreeBac closed system; Changshy Senlin Medical Appliance Ltda., Changshu, China). The urine drainage bag was attached to a thoracic elastic belt ( $80 \mathrm{~mm}$ width) so that cows had free movement inside the pen during collections.

After every spontaneous urination, urine was transferred to containers $(30 \mathrm{~L})$ containing $500 \mathrm{~mL}$ of sulfuric acid (40\%), which maintained the urine $\mathrm{pH}$ below 3 while avoiding PD microbial degradation (Chen and Gomes, 1992) and ammonia volatilization (Plaizier et al., 2000). By the end of the 24-h periods, urine production was measured and a representative sample was collected. Twenty milliliters of urine was diluted in 80 $\mathrm{mL}$ of distilled water to avoid uric acid crystals and precipitation in samples. These samples were filtered in a Whatman filter and analyzed for PD; allantoin was analyzed according to Fujihara et al. (1987) using a microplate reader (Expert Plus, Asys Hitech GMBH, Eugenorf, Austria) and uric acid was analyzed using a commercial kit (K139, Bioclin, Belo Horizonte, Brazil), absorbances were measured in a spectrophotometer (SBA 200, CELM, São Caetano do Sul, Brazil). Milk samples were collected during 4 consecutive milkings on d 17 and 18 of each period. Samples were deproteinized with trichloroacetic acid solution (25\%), filtered in Whatman filter, and analyzed for allantoin concentration as described earlier.

Daily PD excretion was calculated as the sum of allantoin and uric acid excreted in urine and the amounts of allantoin secreted in milk $(\mathrm{mmol} / \mathrm{d})$. Absorbed microbial purines (absP) was calculated from PD excretion, where absP $=\left(\mathrm{PD}-0.236 \times \mathrm{BW}^{0.75}\right) \div 0.84$, in which $0.236 \mathrm{mmol} / \mathrm{kg}$ of $\mathrm{BW}^{0.75}$ is the $\mathrm{PD}$ endogenous contribution and 0.84 is the recovery coefficient of absP as PD (Orellana Boero et al., 2001). The synthesis of micN (g/d) was estimated according to adapted equation of Chen and Gomes (1992), as follows: micN = $(\operatorname{absP} \times 70) \div(0.83 \times 0.103 \times 1,000)$ where 70 is the $\mathrm{N}$ content of purines ( $\mathrm{mg}$ of $\mathrm{N} / \mathrm{mmol}$ ), 0.83 is the intestinal digestibility coefficient of microbial purines, and 0.103 is the $\mathrm{N}$ in purines to $\mathrm{N}$ in ruminal bacteria ratio obtained in this study. The $\mathrm{N}$ in purines to total $\mathrm{N}$ in bacteria ratio values were obtained after the bacteria extraction from ruminal digesta samples. The bacterial pellet was lyophilized, macerated, and analyzed for DM and total N (AOAC International, 2000; methods 930.15 and 990.3, respectively), and total purines (Makkar and Becker, 1999). The efficiency of $\mathrm{N}$ utilization for micN synthesis was calculated as the $[\mathrm{micN}(\mathrm{g} / \mathrm{d}) \div \mathrm{N}$ intake $(\mathrm{g} / \mathrm{d})] \times 100$. The apparent $\mathrm{OM}$ degradation in rumen was estimated as $\{[\mathrm{OM}$ intake $(\mathrm{kg} / \mathrm{d}) \div$ total apparent digestibility of $\mathrm{OM}(\%)] \times 100\} \times 0.65$, according to ARC (1984). Utilization efficiency of $\mathrm{N}$ intake to milk production was calculated as $[$ milk $\mathrm{N}(\mathrm{g} / \mathrm{d}) \div 0.93] \div$ $\mathrm{N}$ intake (g/d), according to Dschaaka et al. (2010) wherein the milk $\mathrm{N}$ secretion was calculated as [milk yield $(\mathrm{g} / \mathrm{d}) \times$ milk protein content $(\%)] \div 6.38$.

\section{Milk Yield and Composition, and Blood Metabolites}

Cows were milked twice daily (0600 and $1600 \mathrm{~h}$ ) and milk yield electronically recorded (DeLaval, Tumba, Sweden). Milk samples were collected from d 16 to 19 in all milkings and analyzed for fat, protein, and lactose in an ultrasonic milk analyzer (Lactoscan MCC, Milkotronic Company, Nova Zagora, Bulgaria). Samples collected on d 17 and 18 were deproteinized as described earlier and analyzed for urea concentration using a commercial kit (K056, Bioclin) and absorbance measured in a spectrophotometer (SBA 200, CELM). Milk yield was corrected for 3.5\% fat (FCM) according to the equation proposed by Sklan et al. (1992) where $\mathrm{FCM}=[0.432+0.1625 \times$ milk fat content $(\%)] \times$ milk yield $(\mathrm{kg} / \mathrm{d})$. Energy-corrected milk was calculated as $\mathrm{ECM}=$ milk yield $(\mathrm{kg} / \mathrm{d}) \times 0.327+$ milk fat content $\times$ $12.86+$ milk protein $(\mathrm{kg} / \mathrm{d}) \times 7.65$. Milk samples collected on d 17 and 18 were analyzed for FA profile. Milk sample aliquots $(40 \mathrm{~mL})$ were centrifuged at $17,800 \times$ $g\left(30 \mathrm{~min}\right.$ at $\left.4^{\circ} \mathrm{C}\right)$ followed by another centrifugation of $19,300 \times g\left(20 \mathrm{~min}\right.$ at $\left.4^{\circ} \mathrm{C}\right)$ to collect the fat supernatant (Feng et al., 2004). Lipids extracted from milk samples were methylated according to Kramer at al. (1997). The FAME were quantified by GC as described earlier.

On d 18 of each experimental period, blood samples were collected by venipuncture from the coccygeal vein in vacutainer tubes with no anticoagulants before and $4 \mathrm{~h}$ after the morning feeding. Tubes rested on ice until clot formation, then were centrifuged $(3,000 \times g, 15$ min at room temperature), serum was collected and frozen. Commercial kits (Bioclin) were used to analyze serum glucose (K082) and total cholesterol (K083), and absorbances were measured in a spectrophotometer (SBA 200, CELM). 


\section{Statistical Analysis}

Data were analyzed for normality of residuals (Shapiro-Wilk method) and variance homogeneity (Hartley method) using UNIVARIATE and GLM procedures of SAS 9.2 (SAS Institute Inc., Cary, NC), respectively. The ANOVA of nutrient intake and digestibility, ruminal bacteria population, micN synthesis, blood metabolites, and milk yield and composition data were performed using the MIXED procedure of SAS following the model below:

$$
\begin{aligned}
\mathrm{Y}_{\mathrm{ijklm}}= & \mu+\mathrm{CHI}_{\mathrm{i}}+\mathrm{WRS}_{\mathrm{j}}+\mathrm{CHI}_{\mathrm{i}} \times \mathrm{WRS}_{\mathrm{j}} \\
& +\mathrm{P}_{\mathrm{k}}+\mathrm{S}_{\mathrm{l}}+\mathrm{c}_{\mathrm{m}}\left(\mathrm{S}_{\mathrm{l}}\right)+\mathrm{e}_{\mathrm{ijklm}},
\end{aligned}
$$

where $\mathrm{Y}_{\mathrm{ijklm}}$ is the dependent variable, $\mu$ is the intercept, $\mathrm{CHI}_{\mathrm{i}}$ is the fixed effect of CHI, WRS $\mathrm{S}_{\mathrm{j}}$ is the fixed effect of WRS, $\mathrm{CHI}_{\mathrm{i}} \times \mathrm{WRS}_{\mathrm{j}}$ is the fixed interaction effect of CHI by WRS, $\mathrm{P}_{\mathrm{k}}$ is the fixed effect of period, $\mathrm{S}_{1}$ is the fixed effect of Latin square, $c_{m}\left(S_{l}\right)$ is the random effect of cow nested in Latin square, and $\mathrm{e}_{\mathrm{ijk} \mathrm{km}}$ is the residual.

Ruminal fermentation results were generated from data of 8 cows analyzed as repeated measures by the MIXED procedure of SAS according to the following model:

$$
\begin{aligned}
\mathrm{Y}_{\mathrm{ijklmn}}= & \mu+\mathrm{CHI}_{\mathrm{i}}+\mathrm{WRS}_{\mathrm{j}}+\mathrm{CHI}_{\mathrm{i}} \times \mathrm{WRS}_{\mathrm{j}}+\mathrm{P}_{\mathrm{k}} \\
+\mathrm{S}_{\mathrm{l}}+ & \mathrm{c}_{\mathrm{m}}\left(\mathrm{S}_{\mathrm{l}}\right)+\mathrm{T}_{\mathrm{n}}+\mathrm{T}_{\mathrm{n}} \times \mathrm{CHI}_{\mathrm{i}}+\mathrm{T}_{\mathrm{n}} \times \mathrm{WRS}_{\mathrm{j}} \\
& +\mathrm{T}_{\mathrm{n}} \times \mathrm{CHI}_{\mathrm{i}} \times \mathrm{WRS}_{\mathrm{j}}+\mathrm{e}_{\mathrm{ijklmn}},
\end{aligned}
$$

where $T_{n}$ is the fixed effect of time (h relative to the morning feeding); $\mathrm{T}_{\mathrm{n}} \times \mathrm{CHI}_{\mathrm{i}}$ is the fixed interaction effect of time by CHI; $\mathrm{T}_{\mathrm{n}} \times \mathrm{WRS}_{\mathrm{j}}$ is the fixed interaction effect of time by WRS; $\mathrm{T}_{n} \times \mathrm{CHI}_{\mathrm{i}} \times \mathrm{WRS}_{\mathrm{j}}$ is the fixed interaction effect among time, CHI, and WRS; and $\mathrm{e}_{\mathrm{ijk} k \mathrm{mn}}$ is the residual. The interaction between period and cow within Latin square was used as the error term. Data were submitted to 10 covariance structures for residuals [CS, CSH, UN(1), $\mathrm{AR}(1), \mathrm{ARH}(1), \mathrm{HF}$, TOEP, TOEPH, and VC] and Akaike method was used to choose the best covariance structure, based on the lowest corrected Akaike information criterion value. Means were adjusted by LSMEANS statement. When the $\mathrm{CHI} \times$ WRS interaction effect was $P \leq 0.05$, the PDIFF option was used to produce a protected leastsignificant difference. Fermentation variables data were submitted to F test each time using the SLICE option from LSMEANS. Significance level was set at 0.05, and tendencies were considered when $0.05<P \leq 0.10$.

\section{RESULTS}

Diets containing WRS increased $(P<0.001)$ EE intake, but decreased $(P<0.001) \mathrm{CP}$ total-tract digestibility in cows (Table 2). An interaction effect between $\mathrm{CHI}$ and WRS was observed on intake of DM, OM, $\mathrm{CP}, \mathrm{NDF}$, and NFC, as well as on digestibility of DM, $\mathrm{OM}, \mathrm{NDF}$ and $\mathrm{EE}$ of cows. In general, the combination

\begin{tabular}{|c|c|c|c|c|c|c|c|c|}
\hline \multirow[b]{3}{*}{ Item } & \multicolumn{4}{|c|}{ Treatment $^{1}$} & \multirow[b]{3}{*}{ SEM } & \multirow{2}{*}{\multicolumn{3}{|c|}{$P$-value ${ }^{2}$}} \\
\hline & \multicolumn{2}{|c|}{$\mathrm{CON}$} & \multicolumn{2}{|c|}{ WRS } & & & & \\
\hline & 0 & 4 & 0 & 4 & & $\mathrm{CHI}$ & WRS & $\mathrm{CHI} \times \mathrm{WRS}$ \\
\hline \multicolumn{9}{|l|}{ Intake, $\mathrm{kg} / \mathrm{d}$} \\
\hline DM & $23.7^{\mathrm{ab}}$ & $23.8^{\mathrm{a}}$ & $23.2^{\mathrm{b}}$ & $22.6^{\mathrm{c}}$ & 0.476 & 0.181 & $<0.001$ & 0.028 \\
\hline $\mathrm{OM}$ & $22.1^{\mathrm{ab}}$ & $22.2^{\mathrm{a}}$ & $21.7^{\mathrm{b}}$ & $21.1^{\mathrm{c}}$ & 0.444 & 0.182 & $<0.001$ & 0.030 \\
\hline Ether extract & 0.599 & 0.603 & 1.19 & 1.17 & 0.023 & 0.550 & $<0.001$ & 0.370 \\
\hline NFC & $10.7^{\mathrm{a}}$ & $10.8^{\mathrm{a}}$ & $9.71^{\mathrm{b}}$ & $9.45^{\mathrm{c}}$ & 0.200 & 0.345 & $<0.001$ & 0.029 \\
\hline $\mathrm{NE}_{\mathrm{L}}, \mathrm{Mcal} / \mathrm{d}$ & 36.7 & 36.9 & 37.0 & 36.3 & 0.607 & 0.222 & 0.419 & 0.070 \\
\hline \multicolumn{9}{|c|}{ Total-tract digestibility, $\%$} \\
\hline DM & $69.6^{\mathrm{a}}$ & $69.2^{\mathrm{a}}$ & $67.0^{\mathrm{b}}$ & $64.4^{\mathrm{c}}$ & 0.683 & 0.010 & $<0.001$ & 0.047 \\
\hline $\mathrm{OM}$ & $71.8^{\mathrm{a}}$ & $71.4^{\mathrm{a}}$ & $69.3^{\mathrm{b}}$ & $66.7^{\mathrm{c}}$ & 0.700 & 0.007 & $<0.001$ & 0.043 \\
\hline $\mathrm{CP}$ & 73.8 & 75.5 & 67.2 & 66.6 & 1.574 & 0.570 & $<0.001$ & 0.267 \\
\hline
\end{tabular}
of WRS and CHI decreased nutrient intake (DM, OM, $\mathrm{CP}, \mathrm{NDF}$, and NFC) and digestibility (DM, OM, NDF,

Table 2. Influence of whole raw soybeans (WRS) and chitosan (CHI; 0 or $4 \mathrm{~g} / \mathrm{kg}$ of DM) on nutrient intake and total-tract digestibility of lactating cows

${ }^{\mathrm{a}-\mathrm{c}}$ Values in the same row with a different superscript differ significantly (LSD, $P<0.05$ ).

${ }^{1}$ Control (CON), WRS added at $14 \%$ diet DM, and CHI at 0 or $4 \mathrm{~g} / \mathrm{kg}$ of DM.

${ }^{2}$ Probabilities for effects of CHI, WRS, or the interaction of $\mathrm{CHI}$ and WRS (CHI $\times$ WRS). 
Table 3. Influence of whole raw soybeans (WRS) and chitosan (CHI; 0 or $4 \mathrm{~g} / \mathrm{kg}$ of DM) on ruminal fermentation of lactating cows

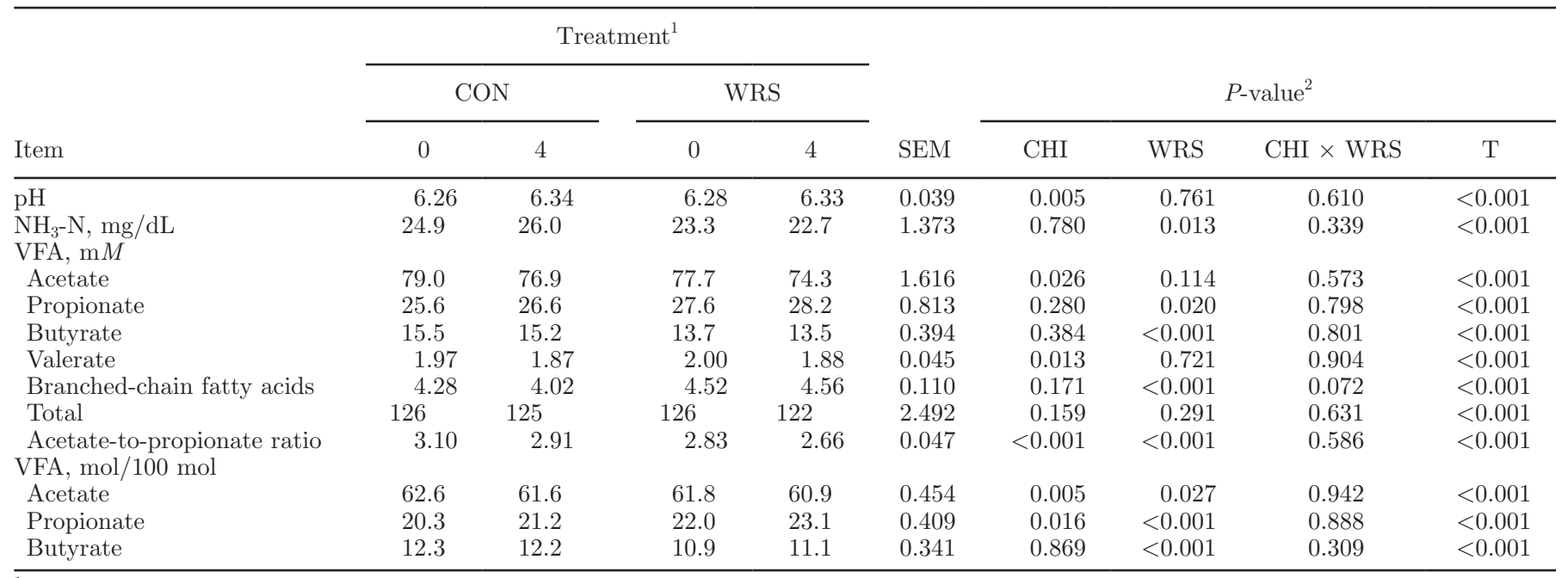

${ }^{1}$ Control (CON), WRS added at $14 \%$ diet DM, and CHI at 0 or $4 \mathrm{~g} / \mathrm{kg}$ of DM.

${ }^{2}$ Probabilities for effects of CHI, WRS, the interaction of CHI and WRS $(\mathrm{CHI} \times$ WRS $)$, and hours relative to the morning feeding $(\mathrm{T})$.

and $\mathrm{EE}$ ) of cows when compared with other treatments. However, cows fed CHI with no WRS in diets exhibited similar nutrient intake and digestibility in comparison with CON.

Regardless of the negative effects of CHI and WRS combination on DMI and nutrient digestibility, no interaction effects were observed in rumen fermentation variables (Table 3). Cows fed CHI had higher $(P \leq$ 0.016 ) ruminal $\mathrm{pH}$ and propionate molar proportion than cows fed no CHI. However, CHI decreased acetate and valerate ruminal concentrations, acetate to propionate ratio, and acetate molar proportion. Diets containing WRS decreased $(P \leq 0.027)$ ruminal $\mathrm{NH}_{3}-\mathrm{N}$ and butyrate concentrations, and the molar proportions of acetate and butyrate while increasing $(P<0.001)$ the molar proportion of propionate in cows. Interaction effect between WRS and time was observed $(P=0.012)$ on ruminal $\mathrm{NH}_{3}-\mathrm{N}$ concentration (Supplemental Figure S1; https://doi.org/10.3168/jds.2018-14675). No other interaction effect between treatment and time were observed in ruminal fermentation variables (data not shown).

No CHI by WRS interaction effects were observed on ruminal bacterial populations assessed in this experiment (Table 4$)$. Chitosan decreased $(P=0.001)$ the relative population of Butyrivibrio group in comparison with the other treatments. Diets containing WRS negatively affected $(P \leq 0.031)$ the rumen bacterial populations from the Butyrivibrio group and F. succinogenes; however, WRS increased $(P<0.001)$ the relative rumen bacterial population of $S$. bovis.

A negative interaction effect between CHI and WRS was detected $(P=0.018)$ on micN (Table 5$)$. The CHI alone had no effect on $\mathrm{N}$ utilization of cows. On the other hand, WRS decreased $(P=0.001)$ urinary $\mathrm{N}$ excretion and increased $(P=0.001)$ fecal $\mathrm{N}$ output. The combination of CHI and WRS negatively affected $(P \leq$ 0.04 ) the $\mathrm{N}$ intake and milk $\mathrm{N}$ secretion of cows.

Diets containing WRS increased $(P=0.008)$ milk fat concentration and decreased $(P \leq 0.012)$ the urea

Table 4. Influence of whole raw soybeans (WRS) and chitosan (CHI; 0 or $4 \mathrm{~g} / \mathrm{kg}$ of DM) on bacterial population in the rumen of lactating cows

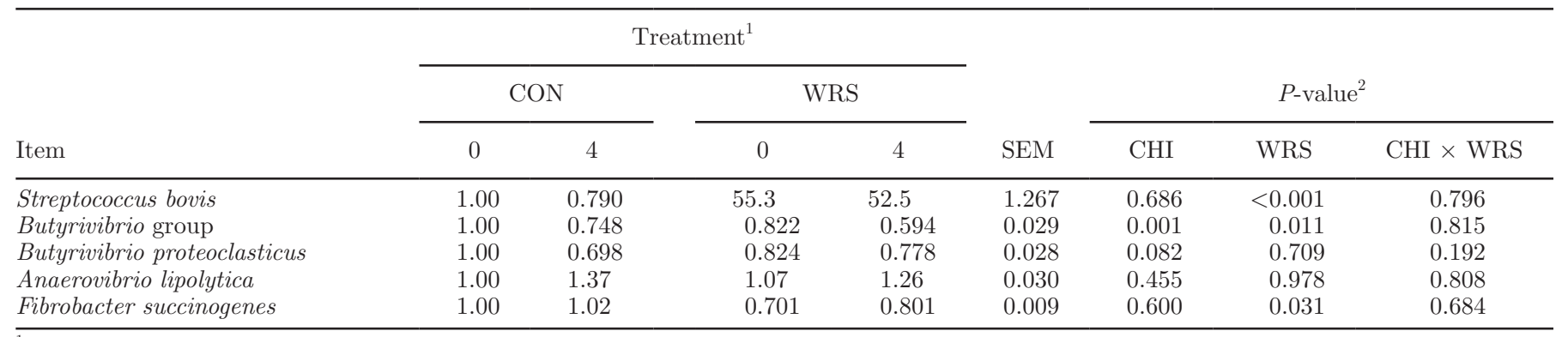

${ }^{1}$ Control (CON), WRS added at 14\% diet DM, and CHI at 0 or $4 \mathrm{~g} / \mathrm{kg}$ of DM. Means expressed as fold change in relation to CON.

${ }^{2}$ Probabilities for effects of CHI, WRS, or the interaction of CHI and WRS (CHI $\times$ WRS). 
Table 5. Influence of whole raw soybeans (WRS) and chitosan (CHI; 0 or $4 \mathrm{~g} / \mathrm{kg}$ of DM) on microbial protein synthesis and $\mathrm{N}$ use in lactating cows

\begin{tabular}{|c|c|c|c|c|c|c|c|c|}
\hline Item & \multicolumn{4}{|c|}{ Treatment $^{1}$} & SEM & \multicolumn{3}{|c|}{$P$-value ${ }^{2}$} \\
\hline Microbial N, g/d & $317^{\mathrm{a}}$ & $331^{\mathrm{a}}$ & $305^{\mathrm{a}}$ & $263^{\mathrm{b}}$ & 22.8 & 0.202 & 0.002 & 0.018 \\
\hline Microbial $\mathrm{N} \div$ rumen degradable $\mathrm{OM}, \mathrm{g} / \mathrm{kg}$ & 32.6 & 34.1 & 33.3 & 31.0 & 1.88 & 0.753 & 0.358 & 0.142 \\
\hline Microbial $\mathrm{N} \div \mathrm{N}$ intake, $\mathrm{g} / \mathrm{g}$ & 0.493 & 0.515 & 0.471 & 0.433 & 0.0241 & 0.604 & 0.004 & 0.068 \\
\hline Urinary $\mathrm{N}, \mathrm{g} / \mathrm{d}$ & 252 & 246 & 218 & 213 & 17.7 & 0.488 & 0.001 & 0.928 \\
\hline Fecal N, g/d & 169 & 159 & 213 & 203 & 15.2 & 0.205 & $<0.001$ & 0.980 \\
\hline
\end{tabular}

${ }^{a-c}$ Values in the same row with a different superscript differ significantly (LSD, $P<0.05$ ).

${ }^{1}$ Control (CON), WRS added at $14 \%$ diet DM, and CHI at 0 or $4 \mathrm{~g} / \mathrm{kg}$ of DM.

${ }^{2}$ Probabilities for effects of CHI, WRS, or the interaction of CHI and WRS (CHI $\times$ WRS).

concentration in milk, and efficiency of milk $\mathrm{N}$ production of cows (Table 6). The combination of CHI and WRS negatively affected $(P \leq 0.017)$ yields of milk, FCM, ECM, protein, and lactose of cows. In terms of milk synthesis efficiency, cows fed diets with CHI and without WRS had the highest values of feed efficiency $(\mathrm{FCM} \div \mathrm{DMI}$ and $\mathrm{ECM} \div \mathrm{DMI})$, whereas cows fed diets with WRS had intermediate values, and CON ex- hibited the lowest values of feed efficiency. The CHI had no effect on blood metabolites, but WRS decreased $(P$ $=0.010)$ blood concentrations of glucose and increased $(P<0.001)$ blood concentration of total cholesterol.

Chitosan decreased milk concentration of 4:0, 6:0, 8:0, total SFA, SFA to UFA ratio, and 18:0 to UFA ratio (Table 7 ). On the other hand, CHI increased milk concentration of $18: 1$ trans-11, 18:2 cis-9,cis-12, 18:3

Table 6. Influence of whole raw soybeans (WRS) and chitosan (CHI; 0 or $4 \mathrm{~g} / \mathrm{kg}$ of DM) on efficiency of milk production and blood metabolites of lactating cows

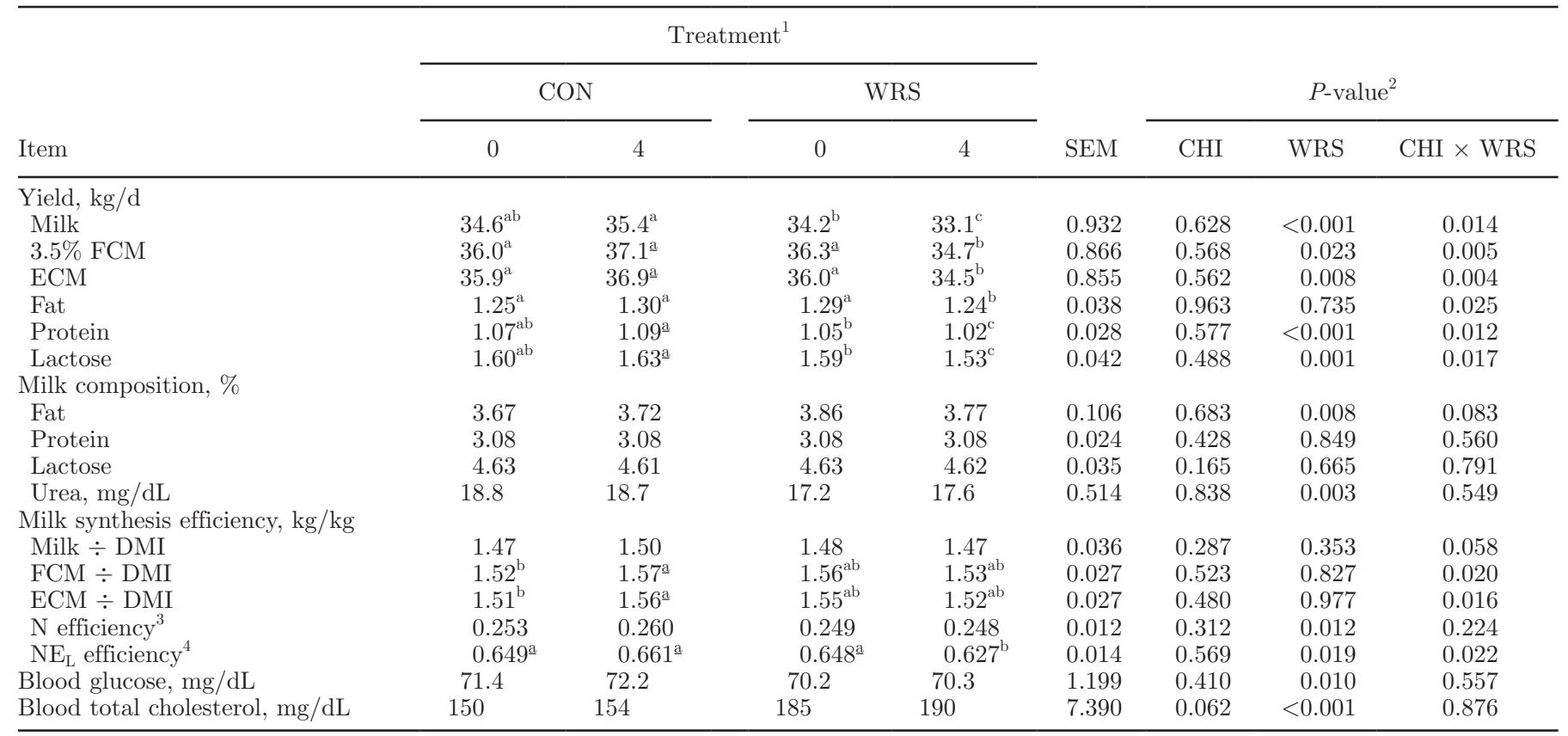

\footnotetext{
${ }^{a-c}$ Values in the same row with a different superscript differ significantly (LSD, $P<0.05$ ).

${ }^{1}$ Control (CON), WRS added at $14 \%$ diet DM, and CHI at 0 or $4 \mathrm{~g} / \mathrm{kg}$ of DM.

${ }^{2}$ Probabilities for effects of CHI, WRS, or the interaction of CHI and WRS (CHI $\times$ WRS).

${ }^{3}$ Efficiency of $\mathrm{N}=\{[$ milk protein $(\mathrm{kg} / \mathrm{d}) \div 0.93] \div 6.38\} \div \mathrm{N}$ intake $(\mathrm{kg} / \mathrm{d})$, according to Dschaaka et al. (2010).

${ }^{4}$ Net energy of lactation efficiency $=\mathrm{NE}_{\mathrm{L}}$ milk $\div \mathrm{NE}_{\mathrm{L}}$ intake.
} 
cis-9,cis-12,cis-15, 18:1 cis-9,trans-11, total MUFA, and total PUFA. In addition, CHI increased the product to substrate ratio of 18:1 cis-9 to 18:0. Diets containing WRS decreased FA concentration in milk of all FA up to 16 carbon chain length. Furthermore, WRS increased 18:0, 18:1 cis-9, 18:2 cis-9, cis-12, 18:3 cis-9, cis-12,cis-15, 20:0, and 20:3 cis-8,cis-11,cis-14 FA concentrations in milk of cows. In summary, WRS increased long-chain FA ( $>$ C16), total MUFA, PUFA, and 18:0 to UFA ratio in milk of cows. The WRS decreased total SFA, FA with odd carbon chain, and total SFA to UFA ratio in milk of cows. Finally, WRS decreased the product-to- substrate ratios of $14: 1 \mathrm{cis}-9$ to $14: 0,16: 1$ cis-9 to $16: 0$, and 18:1 cis-9 to $18: 0$.

\section{DISCUSSION}

To the best of our knowledge, no data are available regarding the effects of CHI and WRS on nutrient digestibility, metabolic profile, and performance of lactating dairy cows. Gandra et al. (2016b) evaluated the combination of CHI and WRS in diets of Jersey heifers and did not report interaction effects on nutrient digestion, microbial protein synthesis, and blood metabo-

Table 7. Influence of whole raw soybeans (WRS) and chitosan (CHI; 0 or $4 \mathrm{~g} / \mathrm{kg}$ of DM) on milk fatty acid (FA) profile of lactating cows $(\mathrm{g} / 100 \mathrm{~g}$ of $\mathrm{FA})$

\begin{tabular}{|c|c|c|c|c|c|c|c|c|}
\hline \multirow[b]{3}{*}{ Item } & \multicolumn{4}{|c|}{ Treatment $^{1}$} & \multirow[b]{3}{*}{ SEM } & \multirow{2}{*}{\multicolumn{3}{|c|}{$P$-value ${ }^{2}$}} \\
\hline & \multicolumn{2}{|c|}{$\mathrm{CON}$} & \multicolumn{2}{|c|}{ WRS } & & & & \\
\hline & 0 & 4 & 0 & 4 & & $\mathrm{CHI}$ & WRS & $\mathrm{CHI} \times \mathrm{WRS}$ \\
\hline 4:0 & 1.44 & 1.43 & 1.43 & 1.39 & 0.018 & 0.044 & 0.042 & 0.237 \\
\hline $6: 0$ & 1.59 & 1.56 & 1.50 & 1.47 & 0.020 & 0.030 & $<0.001$ & 0.777 \\
\hline $8: 0$ & 1.17 & 1.13 & 1.04 & 1.02 & 0.024 & 0.026 & $<0.001$ & 0.450 \\
\hline $10: 0$ & 3.03 & 2.92 & 2.55 & 2.52 & 0.090 & 0.105 & $<0.001$ & 0.371 \\
\hline $11: 0$ & 0.087 & 0.083 & 0.067 & 0.064 & 0.008 & 0.495 & $<0.001$ & 0.929 \\
\hline $12: 0$ & 3.79 & 3.64 & 3.04 & 3.03 & 0.120 & 0.175 & $<0.001$ & 0.261 \\
\hline $13: 0$ & 0.235 & 0.246 & 0.197 & 0.191 & 0.013 & 0.670 & $<0.001$ & 0.215 \\
\hline $14: 0$ & 11.8 & 11.5 & 10.1 & 10.2 & 0.200 & 0.310 & $<0.001$ & 0.225 \\
\hline cis-9 14:1 & 1.00 & 0.98 & 0.74 & 0.77 & 0.036 & 0.674 & $<0.001$ & 0.119 \\
\hline $15: 0$ & 1.10 & 1.12 & 0.97 & 0.96 & 0.044 & 0.733 & $<0.001$ & 0.691 \\
\hline $16: 0$ & 33.0 & 32.6 & 29.1 & 29.2 & 0.511 & 0.497 & $<0.001$ & 0.256 \\
\hline cis-9 16:1 & 1.44 & 1.46 & 1.15 & 1.22 & 0.047 & 0.056 & $<0.001$ & 0.347 \\
\hline $17: 0$ & 0.626 & 0.626 & 0.538 & 0.533 & 0.011 & 0.717 & $<0.001$ & 0.679 \\
\hline $18: 0$ & 9.64 & 9.44 & 13.4 & 12.5 & 0.275 & 0.014 & $<0.001$ & 0.124 \\
\hline cis-9 18:1 & 22.0 & 22.7 & 25.5 & 25.8 & 0.591 & 0.092 & $<0.001$ & 0.418 \\
\hline trans-9 18:1 & 0.192 & 0.193 & 0.185 & 0.190 & 0.006 & 0.350 & 0.139 & 0.482 \\
\hline trans-11 18:1 & 0.623 & 0.681 & 0.500 & 0.549 & 0.020 & $<0.001$ & $<0.001$ & 0.743 \\
\hline cis-9,cis-12 $18: 2$ & 2.31 & 2.38 & 3.06 & 3.17 & 0.060 & 0.048 & $<0.001$ & 0.633 \\
\hline cis-9,cis-12,cis-15 18:3 & 0.160 & 0.173 & 0.283 & 0.311 & 0.008 & 0.003 & $<0.001$ & 0.246 \\
\hline cis-9,trans-11 CLA & 0.354 & 0.394 & 0.284 & 0.324 & 0.016 & $<0.001$ & $<0.001$ & 0.951 \\
\hline $20: 00$ & 0.109 & 0.108 & 0.133 & 0.128 & 0.003 & 0.085 & $<0.001$ & 0.243 \\
\hline cis-11 20:1 & 0.007 & 0.010 & 0.007 & 0.007 & 0.004 & 0.275 & 0.335 & 0.335 \\
\hline cis-8,cis-11,cis-14 20:3 & 0.107 & 0.108 & 0.117 & 0.112 & 0.005 & 0.551 & 0.023 & 0.322 \\
\hline cis-5,cis-8,cis-11,cis-14 20:4 & 0.157 & 0.161 & 0.160 & 0.160 & 0.005 & 0.400 & 0.646 & 0.463 \\
\hline$\Sigma$ not identified & $4.19^{\mathrm{a}}$ & $4.16^{\mathrm{a}}$ & $3.96^{\mathrm{b}}$ & $4.11^{\mathrm{a}}$ & 0.087 & 0.147 & 0.002 & 0.036 \\
\hline \multicolumn{9}{|l|}{ Summary } \\
\hline$\Sigma 4 \mathrm{C}$ to $14 \mathrm{C}$ & 23.8 & 23.2 & 20.3 & 20.2 & 0.445 & 0.149 & $<0.001$ & 0.367 \\
\hline$\Sigma$ more than $16 \mathrm{C}$ & 36.5 & 37.2 & 44.2 & 43.6 & 0.726 & 0.991 & $<0.001$ & 0.107 \\
\hline$\Sigma \mathrm{SFA}$ & 67.5 & 66.6 & 63.8 & 63.2 & 0.685 & 0.022 & $<0.001$ & 0.650 \\
\hline$\Sigma$ MUFA & 25.2 & 26.1 & 28.1 & 28.6 & 0.586 & 0.043 & $<0.001$ & 0.494 \\
\hline$\Sigma$ PUFA & 3.09 & 3.23 & 3.92 & 4.09 & 0.084 & 0.006 & $<0.001$ & 0.715 \\
\hline$\Sigma$ Odd carbon chain FA & 2.07 & 2.08 & 1.75 & 1.75 & 0.074 & 0.937 & $<0.001$ & 0.985 \\
\hline SFA-to-UFA ratio & 2.41 & 2.29 & 2.00 & 1.95 & 0.065 & 0.012 & $<0.001$ & 0.273 \\
\hline C18 SFA-to-UFA ratio & 0.379 & 0.357 & 0.452 & 0.415 & 0.011 & $<0.001$ & $<0.001$ & 0.268 \\
\hline \multicolumn{9}{|l|}{ Product-to-substrate ratio } \\
\hline cis-9 $14: 1$ to $14: 0$ & 0.086 & 0.087 & 0.073 & 0.077 & 0.003 & 0.068 & $<0.001$ & 0.205 \\
\hline cis-9 $16: 1$ to $16: 0$ & 0.044 & 0.045 & 0.040 & 0.042 & 0.001 & 0.121 & 0.001 & 0.270 \\
\hline cis-9 $18: 1$ to $18: 0$ & 2.30 & 2.43 & 1.92 & 2.07 & 0.062 & $<0.001$ & $<0.001$ & 0.946 \\
\hline cis-9,trans-11 CLA to trans-11 18:1 & 0.581 & 0.590 & 0.568 & 0.599 & 0.020 & 0.089 & 0.852 & 0.347 \\
\hline
\end{tabular}

\footnotetext{
${ }^{a-c}$ Values in the same row with a different superscript differ significantly (LSD, $P<0.05$ ).

${ }^{1}$ Control (CON), WRS added at $14 \%$ diet DM, and CHI at 0 or $4 \mathrm{~g} / \mathrm{kg}$ of DM.

${ }^{2}$ Probabilities for effects of CHI, WRS, or the interaction of CHI and WRS $(\mathrm{CHI} \times \mathrm{WRS})$.
} 
lites. However, the DMI level $(5.98 \mathrm{~kg} / \mathrm{d}$ in average $)$ and WRS dietary inclusion ( $16.3 \%$ diet DM), besides physiological state, make the comparisons between experiments not reliable. Our research group evaluated CHI provision to cows fed a diet with soybean oil and we found similar interaction effects observed in the current study, including decreased DMI and milk yield (Del Valle et al., 2017). Thus, the hypothesis that supplementing WRS instead of soybean oil could eliminate the negative effects of CHI and UFA supplementation on performance was not accepted.

Provision of $\mathrm{CHI}$ in a diet with no WRS and relatively low EE has not altered nutrient intake in ruminants (Goiri et al., 2010a; Araújo et al., 2015; Paiva et al., 2016). On the other hand, CHI provision to cows fed a diet containing soybean oil decreases nutrient intake (Del Valle et al., 2017). In agreement with the latter study, the combination of CHI and WRS decreased the intake of nutrients except for EE. In this experiment, the reduced feed intake of cows fed CHI+WRS is likely related to changes in ruminal fermentation and negative effects on nutrient digestibility. Although the exact mechanism of CHI on the gastrointestinal tract of cows is not fully understood, changes in ruminal fermentation and nutrient utilization (Goiri et al., 2010a; Araújo et al., 2015; Paiva et al., 2016) are very similar to those observed when feeding ionophores (Ipharraguerre and Clark, 2003; Duffield et al., 2008). Similar to ionophores and CHI, UFA affect ruminal metabolism by altering ruminal microbial population (Jenkins, 1993; Lourenço et al., 2010). In the current study, changes in ruminal fermentation were observed when providing to cows either CHI or WRS including an increase in ruminal molar proportion of propionate and a reduction in acetate proportion and acetate to propionate ratio. Regardless of the improvements in fermentation efficiency in terms of energy when CHI was fed with no WRS, nutrient digestibility was not affected. However, when CHI was provided with a diet containing WRS, fiber digestion drastically decreased in comparison with the control treatment (46.7 vs. $38.0 \%$, respectively).

Changes in rumen microbial population (e.g., decreases in gram-positive bacteria and ciliate protozoa and an increase in gram-negative bacteria) and decreased $\mathrm{OM}$ and NDF digestibility can be observed when lipid supplementation exceeds 5\% of dietary FA (Lock and Shingfield, 2004). In addition, the inclusion of lipids in diets increases the release of intestinal peptides regulators that suppress intestinal motility and feed intake of cows (Relling and Reynolds, 2007). Although diets did not exceed $5 \%$ diet EE, decreases in digestibility of $\mathrm{OM}$ and NDF, and reduced NDF intake were observed in the current experiment. The WRS have relatively lower ruminal availability of FA (Barletta et al., 2016), but seemed to affect fiber digestion. According to NRC (2001), the adverse effects of oilseeds on ruminal fermentation depend on diet composition besides the inclusion level, whereas the negative effects of oilseeds are more evident in corn-silage-based diets with low forage proportion. Specific PUFA, such as linoleic acid (present in high amounts in WRS), have toxic effects on cellulolytic and butyrate producing bacteria (Maia et al., 2007, 2010; Yang et al., 2009).

According to Lourenço et al. (2010), the manipulation of a specific microbial activity, such as reduction of biohydrogenation, will always influence other microbial activities in the rumen, particularly the cellulolytic activity. For instance, Butyrivibrio fibrisolvens, which is part of the Butyrivibrio group (major group related to biohydrogenation), has a critical role in fiber digestion, and some species within this group have high proteolytic capacity (Maia et al., 2010). However, B. fibrisolvens is susceptible to the bacteriostatic effects of UFA (Maia et al., 2010). Our results suggest that B. fibrisolvens was affected by the inclusion of WRS in diets, resulting in decreased $\mathrm{CP}$ digestibility. Changes in ruminal bacteria population of cows fed WRS are likely the main cause of decreases in $\mathrm{CP}$ digestibility and ruminal $\mathrm{NH}_{3}-\mathrm{N}$ concentration. According to Ferme et al. (2004), the major ammonia-producing bacteria are Prevotella ruminantium and Prevotella bryantii, and the latter have low tolerance to PUFA (Maia et al., 2007). In addition, UFA exert toxic effects on protozoa ruminal population, decreasing their predatory and proteolytic activities with consequent reduction of $\mathrm{NH}_{3}-\mathrm{N}$ production (Doreau and Ferlay, 1995; Eugène et al., 2004). However, measures of rumen population of $P$. bryantii and protozoa were not performed in this study. The reduction of $\mathrm{NH}_{3}-\mathrm{N}$ in rumen of cows fed WRS may also be related to the lower urea dietary inclusion in diets with WRS in comparison with the other treatments. Although CHI presented a similar negative effect of WRS on Butyrivibrio group population, it did not affect $\mathrm{CP}$ digestibility and ruminal $\mathrm{NH}_{3}-\mathrm{N}$ concentration, suggesting that B. fibrisolvens was not the major bacteria affected within the Butyrivibrio group. In addition, improvements in $\mathrm{CP}$ digestibility have been reported when feeding $\mathrm{CHI}$ to lactating cows (Paiva et al., 2016; Vendramini et al., 2016; Del Valle et al., 2017).

The combination of CHI and WRS decreased totaltract digestibility of EE. Earlier studies evaluating CHI dietary supplementation did not report differences in EE digestibility of lactating cows (Paiva et al., 2016; Del Valle et al., 2017). Nevertheless, Zhang et al. (2008) observed that CHI has hypolipidemic activity 
in high-fat diet fed mice with reduction in plasmatic and hepatic levels of lipids and increase in lipids fecal excretion - effects attributed to a decrease in intestinal fat absorption. Chitosan has high adherence capacity to fat in vitro due to its polycationic structure (Cho et al., 1998). Similar response to CHI was observed in broilers, which exhibited lower ileal digestion of fat, and no changes on $\mathrm{CP}$ and starch digestibility (Razdan and Petterson, 1994). Authors from the latter study speculated possible effects of CHI on digesta viscosity that could impair the activity of intestinal lipases in feed particles or glucosamine groups in CHI acting as a chelator of lipid micelles.

Regarding ruminal fermentation, this study demonstrated that $\mathrm{CHI}$ maintained $\mathrm{pH}$ at higher values when compared with the other treatments, but the increase of ruminal $\mathrm{pH}(+0.06)$ due to $\mathrm{CHI}$ provision is of minimal biological significance. Although previous studies did not find differences in rumen $\mathrm{pH}$ (Goiri et al., 2010a; Paiva et al., 2016; Del Valle et al., 2017), an in vitro study demonstrated higher $\mathrm{pH}$ values when $\mathrm{CHI}$ was added to the batch cultures (Goiri et al., 2009). Whole raw soybeans had no influence on ruminal $\mathrm{pH}$, despite the unexpected increase of $S$. bovis in cows fed WRS. Streptococcus bovis (Firmicutes) have high amylolytic activity and are the main lactate producers in the rumen, often associated with ruminal acidosis (Russell and Strobel, 1989). We expected that the inclusion of WRS in diets would decrease the relative population of $S$. bovis because the inclusion of WRS implies in a reduction of dietary NFC (main substrate for S. bovis). In agreement with the current study, Rico et al. (2015) reported an increase (380\%) in the relative population of $S$. bovis when the dietary content of FA was increased by $2 \%$. The positive effects of UFA on $S$. bovis may be related to their tolerance to PUFA, despite their susceptibility to ionophores (Russell and Strobel, 1989).

The negative effects of CHI and WRS combination were also observed on micN production. Several factors can be related to micN production reduction including changes in ruminal fermentation and bacterial populations, and decreased feed intake and nutrient digestibility of cows fed WRS+CHI. In addition, evidence indicates that $\mathrm{CHI}$ can inhibit ciliate protozoal populations in a lower degree in comparison with vegetable oils (Wencelová et al., 2014). The inhibitory effects of lipids on protozoa can improve the efficiency of microbial protein synthesis even with a reduction of OM and NDF digestibility (Doreau and Ferlay, 1995; Eugène et al., 2004). In terms of $\mathrm{N}$ utilization, the combination of WRS and CHI reduced milk $\mathrm{N}$ secretion due to lower $\mathrm{N}$ intake, $\mathrm{CP}$ digestibility, and micN synthesis of cows. Cows fed WRS exhibited greater $\mathrm{N}$ excretion in feces and lower $\mathrm{N}$ excretion in urine, which are related to the lower CP digestibility of cows fed WRS in comparison with other treatments.

The negative influence of WRS+CHI on DMI, digestion, and metabolism of cows decreased the production of milk, FCM, ECM, and milk solids in relation to the other treatments. The increase in milk fat content of cows fed WRS can be attributed to a decrease in milk yield rather than an increase of fat synthesis in the mammary gland because the total milk fat production was similar in comparison with the control group. Agreeing with the current experiment, Venturelli et al. (2015) reported a linear increase in milk fat content and a linear decrease in milk yield when cows were fed increasing dietary levels of WRS. Cows fed WRS exhibited lower milk urea concentration than other treatments due to the lower $\mathrm{CP}$ digestibility, $\mathrm{NH}_{3} \mathrm{~N}$ ruminal concentration, and blood urea concentration. Interestingly, cows fed CHI and no WRS exhibited the highest values of milk yield and similar total fat production, and consequently exhibited the highest values of feed efficiency in terms of FCM and ECM. Paiva et al. (2016) reported a linear increase on milk yield of cows fed CHI, but the authors did not calculate feed efficiency of cows considering fat or energy production. The increase in blood cholesterol concentrations when feeding WRS to cows is related to an increase of EE intake. Dietary fat supplementation often increases the lipoprotein cholesterol exportation by the intestine, the major site of cholesterol synthesis in ruminants (Noble, 1981). In agreement with the current study, Naves et al. (2016) fed WRS to lactating cows and reported a trend to decreased blood glucose concentration and an increase in blood cholesterol concentration.

In the current study, feeding CHI to cows fed a diet with no WRS increased the concentrations of MUFA and PUFA in milk, whereas similar results were reported by Del Valle et al. (2017). Among the positive effects of $\mathrm{CHI}$ on milk FA profile observed in the current study, we highlight the increase $(12.9 \%)$ of cis-9,trans-11 CLA concentration in milk, which has been related to health benefits in humans (Parodi, 2001; Benjamin and Spener, 2009). Although literature lacks sufficient data regarding the effects of $\mathrm{CHI}$ on biohydrogenation, Goiri et al. (2010b) reported that CHI inhibited the complete biohydrogenation of PUFA from sunflower oil and canola meal and increased the concentrations of trans-11 18:1 and CLA in an in vitro study. In the current study, we quantified 2 bacterial species involved in ruminal lipolysis (A. lipolytica) and lipid transformation ( $S$. bovis) and bacteria involved with FA biohydrogenation (Butyrivibrio group and $B$. proteoclasticus). In addition, we quantified $F$. succino- 
genes, the major cellulolytic bacteria in rumen that is susceptible to antimicrobial effect of CHI (Belanche et al., 2016).

Chitosan decreased or tended to decrease bacterial populations related to ruminal biohydrogenation (Butyrivibrio group and B. proteoclasticus), whereas WRS supplementation decreased $F$. succinogenes and Butyrivibrio group, which corroborates with the decreased digestibility of NDF in cows fed WRS. Feeding WRS increased S. bovis population. Although the latter specie is often associated with lactate production in rumen, some studies (Hudson et al., 1998; Hudson et al., 2000) indicated the $S$. bovis easily hydrate linoleic acid to 13-hydroxy-9-octadecenoic acid. The FA hydration competes with biohydrogenation processes in the rumen (Hudson et al., 1998; Hudson et al., 2000), which could be related to the relative low concentration of intermediates of biohydrogenation in milk of cows fed WRS.

\section{CONCLUSIONS}

Provision of CHI to dairy cows fed a diet supplemented with WRS alters the ruminal fermentation and bacterial population, increasing the milk content of UFA, but decreases nutrient intake and digestibility, microbial protein synthesis, and milk yield. However, evidence indicates that CHI provision in diets with no lipid supplementation improves feed efficiency of lactating cows, besides increasing the milk content of UFA and cis-9,trans-11 CLA. Feeding WRS instead of soybean oil as a fat source did not avoid the negative interaction effects with CHI on performance of cows and unchanged milk FA profile.

\section{ACKNOWLEDGMENTS}

The authors are grateful to the University of São Paulo (São Paulo, Brazil) and Dairy Cattle Research Laboratory (Pirassununga, Brazil) for providing the infrastructure and staff necessary for this study. The authors express appreciation to São Paulo Research Foundation (São Paulo, Brazil) for the fellowship provided to F. Zanferari (grant \#14/15302-5) and to the National Council for Scientific and Technological Development (CNPq, Brasília, Brazil; process \#483302/2013-9).

\section{REFERENCES}

Ahvenjärvi, S., and P. Huhtanen. 2002. Supplementing barley or rapeseed meal to dairy cows fed grass-red clover silage: I. Rumen degradability and microbial flow. J. Anim. Sci. 80:2176-2187.

AOAC International. 2000. Official Methods of Analysis. 17th ed. AOAC Int., Arlington, VA.
Araújo, A. P. C., B. C. Venturelli, M. C. B. Santos, R. Gardinal, N. R B. Cônsolo, G. D. Calomeni, J. E. Freitas Júnior, R. V. Barletta, J. R. Gandra, P. G. Paiva, and F. P. Rennó. 2015. Chitosan affects total nutrients digestion and ruminal fermentation in Nellore steers. Anim. Feed Sci. Technol. 206:114-118.

ARC. 1984. The Nutrient Requirements of Ruminant Livestock (Suppl. 1). Commonwealth Agricultural Bureaux, Farnham Royal, UK.

Barletta, R. F., J. R. Gandra, V. P. Bettero, C. E. Araujo, T. A. Del Valle, G. F. Almeida, E. F. Jesus, R. D. Mingoti, B. C. Benevento, J. E. Freitas Junior., and F. P. Renno. 2016. Ruminal biohydrogenation and abomasal flow of fatty acids in lactating cows: Oilseed provides ruminal protection for fatty acids. Anim. Feed Sci. Technol. 219:111-121.

Beauchemin, K. A., M. Kreuzer, F. O'Mara, and T. A. McAllister. 2008. Nutritional management for enteric methane abatement: A review. Aust. J. Exp. Agric. 48:21-27.

Belanche, A, E. Pinloche, D. Preskett, and C. J. Newnold. 2016. Effects and mode of action of chitosan and ivy fruit saponins on the microbiome, fermentation and methanogenesis in the rumen simulation technique. FEMS Microbiol. Ecol. 92:01-13.

Benjamin, S., and F. Spener. 2009. Conjugated linoleic acids as functional food: An insight into their health benefits. Nutr. Metab. (Lond.) 6:36.

Bettero, V. P., T. A. Del Valle, R. V. Barletta, C. E. Araújo, E. F. Jesus, G. F. Almeida, C. S. Takiya, F. Zanferari, P. G. Paiva, J. E. Freitas Júnior, and F. P. Rennó. 2017. Use of protected fat sources to reduce fatty acid biohydrogenation and improve abomasal flow in dry dairy cows. Anim. Feed Sci. Technol. 224:30-38.

Boeckaert, C., V. Fievez, L. Maignien, J. Dijstra, and N. Boon. 2008. Accumulation of trans C18:1 fatty acids in the rumen after dietary algal supplementation is associated with changes in the Butyrivibrio community. Appl. Environ. Microbiol. 74:6923-6930.

Broderick, G. A., and J. H. Kang. 1980. Automated simultaneous determination of ammonia and total amino acids in ruminal fluid and in vitro media. J. Dairy Sci. 63:64-75.

Chen, X. B., and M. J. Gomes. 1992. Estimation of Microbial Protein Supply to Sheep and Cattle Based on Urinary Excretion of $\mathrm{Pu}-$ rine Derivatives-An Overview of Technical Details. (Occasional publication) International Feed Research Unit. Rowett Research Institute, Bucksburn, Aberdeen, Scotland. 21 pp.

Chilliard, Y., C. Martin, J. Ruel, and M. Doreau. 2009. Milk fatty acids in dairy cows fed whole crude linseed, extruded linseed, or linseed oil, and their relationship with methane output. J. Dairy Sci. 92:5199-5211.

Cho, Y. I., H. K. No, and S. P. Meyers. 1998. Physicochemical characteristics and functional properties of various commercial chitin and chitosan products. J. Agric. Food Chem. 46:3839-3843.

Daetz, R., F. Cunha, J. H. Bittar, C. A. Risco, F. Magalhaes, Y. Maeda, J. E. P. Santos, K. C. Jeong, R. F. Cooke, and K. N. Galvão. 2016. Clinical response after chitosan microparticle administration and preliminary assessment of efficacy in preventing metritis in lactating dairy cows. J. Dairy Sci. 99:8946-8955.

Del Valle, T. A., P. G. Paiva, E. F. Jesus, G. F. Almeida, F. Zanferari, A. G. V. B. Costa, I. C. S. Bueno, and F. P. Rennó. 2017. Dietary chitosan improves nitrogen use and feed conversion in diets for mid-lactation dairy cows. Anim. Feed Sci. Technol. 201:22-29.

Doreau, M., and A. Ferlay. 1995. Effect of dietary lipids on nitrogen metabolism in the rumen: A review. Livest. Prod. Sci. 43:97-110.

Dschaaka, C. M., J. S. Eun, A. J. Young, and J. W. Bergman. 2010. Nutritive merits of whole Nutrasaff safflower seed when fed to Holstein dairy cows during mid lactation. Anim. Feed Sci. Technol. 156:26-36.

Duffield, T. F., A. R. Rabiee, and I. J. Lean. 2008. A meta-analysis of the impact of monensin in lactating dairy cattle. Part 1. Metabolic effects. J. Dairy Sci. 91:1334-1346.

Erwin, E. S., G. J. Marco, and E. M. Emery. 1961. Volatile fatty acid analyses of blood and rumen fluid by gas chromatography. J. Dairy Sci. 44:1768-1771.

Eugène, M., H. Archimède, and D. Sauvant. 2004. Quantitative metaanalysis on the effects of defaunation of the rumen on growth, intake and digestion in ruminants. Livest. Prod. Sci. 85:81-97. 
European Commission. 2003. Regulation (EC) No. 1831/2003 of the European parliament and of the council of 22 September 2003 on additives for use in animal nutrition. Off. J. L268: 229-243.

FDA. 2012. GRAS Notices. GRN No. 443. Accessed May 7, 2018. https://www.accessdata.fda.gov/scripts/fdcc/index.cfm?set= grasnotices\&id $=443$.

Feng, S., A. L. Lock, and P. C. Garnsworthy. 2004. A rapid method for determining fatty acid composition of milk. J. Dairy Sci. $87: 3785-3788$

Ferme, D., M. Banjac, S. Calsamiglia, M. Busquet, C. Kamel, and G. Augustin. 2004. The effects of plant extracts on microbial community structure in a rumen-simulating continuous-culture system as revealed by molecular profiling. Folia Microbiol. (Praha) 49:151-155.

Folch, J., M. Lees, and G. H. Sloane Stanley. 1957. A simple method for the isolation and purification of total lipids from animal tissues. J. Biol. Chem. 226:497-509.

Fujihara, T., E. R. Ørskov, and P. J. Reeds. 1987. The effect of protein infusion on urinary excretion of purine derivatives in ruminants nourished by intragastric nutrition. J. Agric. Food Chem. 109:7-12.

Gandra, J. R., E. R. Oliveira, C. S. Takiya, R. H. T. B. Goes, P. G. Paiva, K. M. P. Oliveira, E. R. S. Gandra, N. D. Orbach, and H. M. C. Haraki. 2016a. Chitosan improves the chemical composition, microbiological quality, and aerobic stability of sugarcane silage. Anim. Feed Sci. Technol. 214:44-52.

Gandra, J. R., C. S. Takiya, E. R. Oliveira, P. G. Paiva, R. H. T. B. Goes, E. R. S. Gandra, and H. M. C. Araki. 2016b. Nutrient digestion, microbial protein synthesis, and blood metabolites of Jersey heifers fed chitosan and whole raw soybeans. Rev. Bras. Zootec. 45:130-137.

Getachew, G., P. H. Robinson, E. J. Depeters, S. J. Taylor, D. D. Gisi, G. E. Higginbotham, and T. J. Riordan. 2005. Methane production from commercial dairy rations estimated using an in vitro gas technique. Anim. Feed Sci. Technol. 123-124:391-402.

Goiri, I., A. Garcia-Rodriguez, and L. M. Oregui. 2009. Effects of chitosans on in vitro rumen digestion and fermentation of maize silage. Anim. Feed Sci. Technol. 148:276-287.

Goiri, I., G. Indurain, K. Insausti, V. Sarries, and A. Garcia-Rodrigues. 2010b. Ruminal biohydrogenation of unsaturated fatty acids in vitro as affected by chitosan. Anim. Feed Sci. Technol. 159:35-40.

Goiri, I., L. M. Oregui, and A. Garcia-Rodriguez. 2010a. Use of chitosan to modulate ruminal fermentation of 50:50 forage-to-concentrate diet in sheep. J. Anim. Sci. 88:749-755.

González-Ronquillo, M., J. Balcells, J. A. Guada, and F. Vicente. 2003. Purine derivative excretion in dairy cows: Endogenous excretion and the effect of exogenous nucleic acid supply. J. Dairy Sci. 86:1282-1291.

Hudson, J. A., Y. Cai, R. J. Corner, B. Morvan, and K. N. Joblin. 2000. Identification and enumeration of oleic acid and linoleic acid hydrating bacteria in the rumen of sheep and cows. J. Appl. Microbiol. 88:286-292.

Hudson, J. A., B. Morvan, and K. N. Joblin. 1998. Hydration of linoleic acid by bacteria isolated from ruminants. FEMS Microbiol. Lett. 169:277-282.

Ipharraguerre, I. R., and J. H. Clark. 2003. Usefulness of ionophores for lactating cows: A review. Anim. Feed Sci. Technol. 106:39-57.

Jenkins, T. C. 1993. Symposium: Advances in ruminant metabolism: Lipid metabolism in the rumen. J. Dairy Sci. 76:3851-3863.

Jeon, S. J., M. Oh, W. Yeo, K. N. Galvão, and K. C. Jeong. 2014. Underlying mechanism of antimicrobial activity of chitosan microparticles and implications for the treatment of infectious diseases. PLoS One 9:e92723.

Khafipour, E., S. Li, J. C. Plaizer, and D. O. Krause. 2009. Rumen microbiome composition determined using two nutritional models of subacute ruminal acidosis. Appl. Environ. Microbiol. 75:71157124 .

Knowlton, K. F., M. S. Allen, and P. S. Erickson. 1996. Lasalocid and particle size of corn grain for dairy cows in early lactation. 1. Effect on ruminal measurements and feeding behavior. J. Dairy Sci. $79: 565-574$.
Kong, M., X. G. Chen, K. Xing, and H. J. Park. 2010. Antimicrobial properties of chitosan and mode of action: A state of art review. Int. J. Food Microbiol. 144:51-63.

Kramer, J. K. G., V. Fellner, M. E. R. Dugan, F. D. Sauer, M. M. Mossoba, and M. P. Yurawec. 1997. Evaluating acid and base catalysts in the methylation of milk and rumen fatty acids with special emphasis on conjugated dienes and total trans fatty acids. Lipids $32: 1219-1228$.

Lanctôt, S., P. Fustier, A. R. Taherian, B. Bisakowski, X. Zhao, and P. Lacasse. 2017. Effect of intramammary infusion of chitosan hydrogels at drying-off on bovine mammary gland involution. J. Dairy Sci. 100:2269-2281.

Licitra, G., T. M. Hernandez, and P. J. Van Soest. 1996. Standardization of procedures for nitrogen fractionation of ruminant feeds. Anim. Feed Sci. Technol. 57:347-358.

Livak, K. J., and T. D. Schmittgen. 2001. Analysis of relative gene expression data using realtime quantitative PCR and the $2^{\Delta \Delta} \mathrm{CT}$ Method. Methods 25:402-408.

Lock, A. L., and K. J. Shingfield. 2004. Optimising milk composition. Pages 107-188 in Dairying-Using Science to Meet Consumers' Needs. E. Kebreab, J. Mills, and D. E. Beever, ed. The British Society of Animal Science Publ. 29. Nottingham University Press, Loughborough, UK.

Lourenço, M., E. Ramos-Morales, and R. J. Wallace. 2010. The role of microbes in rumen lipolysis and lipid metabolism in vitro. J. Dairy Sci. 90:3874-3882.

Maeda, H., C. Fujimoto, Y. Haruki, T. Maeda, S. Kokeguchi, M. Petelin, H. Arai, I. Tanimoto, F. Nishimura, and S. Takashiba. 2003. Quantitative real-time PCR using TaqMan and SYBR Green for Actinobacillusactinomycetemcomitans, Porphyromonasgingivalis, Prevotella intermedia, tetQ gene and total bacteria. FEMS Immunol. Med. Microbiol. 39:81-86.

Maia, M. R. G., L. C. Chaudhary, C. S. Bestwick, A. J. Richardson, N. McKain, T. R. Larson, I. A. Graham, and R. J. Wallace. 2010. Toxicity of unsaturated fatty acids to the biohydrogenating ruminal bacterium, Butyrivibrio fibrisolvens. BMC Microbiol. 10:52.

Maia, M. R. G., L. C. Chaudhary, L. Figeres, and R. J. Wallace. 2007. Metabolism of polyunsaturated fatty acids and their toxicity to the microflora of the rumen. Antonie van Leeuwenhoek 91:303-314.

Makkar, H. P. S., and K. Becker. 1999. Purine quantification in digesta from ruminants by spectrophotometric and HPLC methods. Br. J. Nutr. 81:107-112.

McGuffey, R. K., L. F. Richardson, and J. I. D. Wilkinson. 2001. Ionophores for dairy cattle: Current status and future outlook. J. Dairy Sci. 84 (E. Suppl.):E194-E203.

Mertens, D. R. 2002. Gravimetric determination of amylase-treated neutral detergent fibre in feeds with refluxing beakers or crucibles: collaborative study. J. AOAC Int. 85:1217-1240.

Mingoti, R. D., J. E. Freitas Jr., J. R. Gandra, R. Gardinal, G. D. Calomeni, R. V. Barletta, T. H. A. Vendramini, P. G. Paiva, and F. P. Rennó. 2016. Dose response of chitosan on nutrient digestibility, blood metabolites and lactation performance in Holstein dairy cows. Livest. Sci. 187:35-39.

Mullins, C. R., L. K. Mamedova, M. J. Brouk, C. E. Moore, H. B. Green, K. L. Perfield, J. F. Smith, J. P. Harner, and B. J. Bradford. 2012. Effects of monensin on metabolic parameters, feeding behavior, and productivity of transition dairy cows. J. Dairy Sci. 95:1323-1336.

Naves, A. B., J. E. Freitas Jr., R. V. Barletta, J. R. Gandra, G. D. Calomeni, R. Gardinal, C. S. Takiya, T. H. A. Vendramini, R. D. Mingoti, and F. P. Renno. 2016. Effect of raw soya bean particle size on productive performance and digestion of dairy cows. J. Anim. Physiol. Anim. Nutr. (Berl.) 100:778-788.

Noble, R. C. 1981. Digestion, transport and absorption of lipids. Pages 57-93 in Lipid Metabolism in Ruminant Animals. W. W. Christie, ed. Pergamon Press Ltd., Oxford, UK.

NRC. 2001. Nutrient Requirements of Dairy Cattle. 7th rev. ed. Natl. Acad. Press, Washington, DC.

Orellana-Boero, P., J. Balcells, S. M. Martín-Orúe, J. B. Liang, and J. A. Guada. 2001. Excretion of purine derivatives in cows: Endog- 
enous contribution and recovery of exogenous purine bases. Livest. Prod. Sci. 68:243-250.

Paillard, D., N. McKain, M. T. Rincon, K. J. Shingfield, D. I. Givens, and R. J. Wallace. 2007. Quantification of ruminal Clostridium proteoclasticum by real-time PCR using a molecular beacon approach. J. Appl. Microbiol. 103:1251-1261.

Paiva, P. G., E. Ferreira de Jesus, T. A. Del Valle, G. F. Almeida, A. G. V. B. Costa, C. E. C. Consentini, F. Zanferari, C. S. Takiya, I. C. S. Bueno, and F. P. Rennó. 2016. Effects of chitosan on ruminal fermentation, nutrient digestibility, and milk yield and composition of dairy cows. Anim. Prod. Sci. 57:301-307.

Parodi, P. W. 2001. Cows' milk components with anti-cancer potential. Aust. J. Dairy Technol. 56:65-73.

Plaizier, J. C., A. Martin, T. Duffield, R. Bagg, P. Dick, and B. W. McBride. 2000. Effect of a prepartum administration of monensin in a controlled-release capsule on apparent digestibilities and nitrogen utilization in transition dairy cows. J. Dairy Sci. 83:2918-2925.

Razdan. A., and D. Petterson. 1994. Effect of chitin and chitosan on nutrient digestibility and plasma lipid concentrations in broiler chickens. Br. J. Nutr. 72:277-288.

Relling, A. E., and C. K. Reynolds. 2007. Feeding rumen-inert fats differing in their degree of saturation decreases intake and increases plasma concentrations of gut peptides in lactating dairy cows. J. Dairy Sci. 90:1506-1515.

Rico, D. E., A. W. Holloway, and K. J. Harvatine. 2015. Effect of diet fermentability and unsaturated fatty acid concentration on recovery from diet-induced milk fat depression. J. Dairy Sci. 98:79307943.

Russell, J. B., and H. L. Strobel. 1989. Mini-review: The effect of ionophores on ruminal fermentation. Appl. Environ. Microbiol. 55:1-6.

Sambook, J., and D. W. Russell. 2001. Molecular Cloning-A Laboratory Manual. 3rd ed. Cold Spring Harbor Press, Woodbury, NY.

Schmittgen, T. D., and K. J. Livak. 2008. Analyzing real-time PCR data by the comparative CT method. Nat. Protoc. 3:1101-1108.

Senel, S., and S. J. McClure. 2004. Potential applications of chitosan in veterinary medicine. Adv. Drug Deliv. Rev. 56:1467-1480.

Sklan, D. R., R. Ashkenazi, A. Braun, A. Devorin, and K. Tabori. 1992. Fatty acids, calcium soaps of fatty acids, and cotton seeds fed to high yielding cows. J. Dairy Sci. 75:2463-2472.
Stevenson, D. M., and P. J. Weimer. 2007. Dominance of Prevotella and low abundance of classical ruminal bacterial species in the bovine rumen revealed by relative quantification real-time PCR. Appl. Microbiol. Biotechnol. 75:165-174.

Tajima, K., R. I. Aminov, T. Nagamine, H. Matsui, M. Nakamura, and Y. Benno. 2001. Diet-dependent shifts in the bacterial population of the rumen revealed with real-time PCR. Appl. Environ. Microbiol. 67:2766-2774

Van Nevel, C. J., and D. I. Demeyer. 1988. Manipulation of rumen fermentation. Pages 387-443 in The Rumen Microbial Ecosystem. P. N. Hobson, ed. Elsevier Applied Science, New York, NY.

Vendramini, T. H. A., C. S. Takiya, T. H. Silva, F. Zanferari, M. F Rentas, J. C. Bertoni, C. E. C. Consentini, R. Gardinal, T. S. Acedo, and F. P. Rennó. 2016. Effects of a blend of essential oils, chitosan or monensin on nutrient intake and digestibility of lactating dairy cows. Anim. Feed Sci. Technol. 214:12-21.

Venturelli, B. C., J. E. Freitas Júnior, C. S. Takiya, A. P. C. Araújo, M. C. Santos, G. D. Calomeni, R. Gardinal, T. H. A. Vendramini, and F. P. Rennó. 2015. Total tract nutrient digestion and milk fatty acid profile of dairy cows fed diets containing different levels of whole raw soya beans. J. Anim. Physiol. Anim. Nutr. (Berl.) 99:1149-1160

Weld, K. A., and L. E. Armentano. 2017. The effects of adding fat to diets of lactating dairy cows on total-tract neutral detergent fiber digestibility: A meta-analysis. J. Dairy Sci. 100:1766-1779.

Wencelová, M., Z. Varadyova, K. Mihalikova, S. Kisidayova, and D Jalc. 2014. Evaluating the effects of chitosan, plant oils, and different diets on rumen metabolism and protozoan population in sheep. Turkish J. Vet. Anim. 38:26-33.

Yang, S. L., D. P. Bu, J. Q. Wang, Z. Y. Hu, D. Li, H. Y. Wei, L. Y. Zhou, and J. J. Loor. 2009. Soybean oil and linseed oil supplementation affect profiles of ruminal microorganisms in dairy cows. Animal 3:1562-1569.

Zhang, J., J. Jiu, L. Li, and W. Xia. 2008. Dietary chitosan improves hypercholesterolemia in rats fed high fat diets. Nutr. Res. 28:383390. 